Theoretical Inquiry 



\section{Theoretical Inquiry}

Language, Linguistics, and Literature

Austin E. Quigley

Yale University Press

New Haven \& London 
Copyright (C) 2004 by Austin E. Quigley.

All rights reserved.

This book may not be reproduced, in whole or in part, including illustrations, in any form (beyond that copying permitted by Sections I07 and Io8 of the U.S. Copyright Law and except by reviewers for the public press), without written permission from the publishers.

Set in Adobe Garamond type by The Composing Room of Michigan, Inc. Printed in the United States of America by Sheridan Books.

Library of Congress Cataloging-in-Publication Data

Quigley, Austin E., 1942-

Theoretical inquiry : language, linguistics. and literature / Austin E. Quigley. p. cm.

Includes bibliographical references and index.

ISBN 0-300-IoI66-X (alk. paper)

I. Philology. I. Title.

PI2I.Q49 2004

$80 \mathrm{I}-\mathrm{dc} 2 \mathrm{I}$

2003009885

A catalogue record for this book is available from the British Library.

The paper in this book meets the guidelines for permanence and durability of the Committee on Production Guidelines for Book Longevity of the Council on Library Resources.

I0 987654321 
For Patricia, Caroline, and Catherine 
